\title{
A SMALL WORLD: UNCOVERING HIDDEN DIVERSITY IN FRULLANIA - A NEW SPECIES FROM AOTEAROA-NEW ZEALAND
}

\author{
Matt von KonRaT ${ }^{1}$, Peter de Lange, Juan Larraín, Jörn Hentschel, \\ BENJAMIN CARTER, JON SHaW \& BLANKa SHAW
}

\begin{abstract}
Frullania is a large and taxonomically complex genus. Here a new Frullania, F. toropuku von Konrat, de Lange \& Larraín, sp. nov. is described from New Zealand. Frullania toropuku is placed in F. subg. Microfrullania. The new species is readily recognised by a combination of morphological characters associated with branching, the perianth, sexuality, and sporophyte, which distinguish it from all other New Zealand and regional species of Frullania. However, morphologically F. toropuku most closely resembles the widespread $F$. rostrata, which might well be regarded as a Southern Hemisphere equivalent of the Holarctic $F$. tamarisci species-complex in terms of its cryptic diversity. A combination of morphological characters associated with branching, the perianth, sexuality, and sporophyte distinguish $F$. toropuku from all other New Zealand and regional species of Frullania. A comparison is made between F. toropuku and morphologically allied species of botanical regions outside the New Zealand region and an artificial key is provided. In a prior investigation, maximum parsimony and maximum likelihood analyses of nuclear ribosomal ITS2 and plastidic trnL-trnF sequences from purported related species confirms its independent taxonomic status and corroborates its placement within F. subg. Microfrullania. The ongoing studies of Frullania species-complexes reveal the urgent need for more species-level phylogenies with extensive population sampling to approximate the actual diversity of Frullania, and to elucidate speciation processes and distribution range formation.
\end{abstract}

Keywords: cryptic species, Frullaniaceae, Frullania, Frullania subg. Microfrullania, Frullania toropuku sp. nov., Frullania rostrata, morphology, New Zealand Flora

Matt von Konrat \& Juan Larrain, Science \& Education, The Field Museum, 1400 South Lake Shore Drive, Chicago IL 606052496,U.S.A.; e-mail: mvonkonrat@fieldmuseum.org \& jlarrain@fieldmuseum.org

Peter de Lange, Science and Capability, Department of Conservation, New Zealand; e-mail: pj.delange@xtra.co.nz

Jörn Hentschel, Department of Systematic Botany with Herbarium Haussknecht and Botanical Garden, Friedrich Schiller University, Fürstengraben 1,07743 Jena, Germany; e-mail: j.hentschel@uni-jena.de

Benjamin Carter, Department of Biology, Duke University, Durham, North Carolina, U.S.A.; e-mail: benjamincarter125@ gmail.com

Jon Shaw \& Blanka Shaw, Department of Biology, Duke University, Durham, North Carolina, U.S.A.; e-mail: shaw@duke.edu \&blanka@duke.edu

\section{INTRODUCTION}

Frullania Raddi (Frullaniaceae) is a large, cosmopolitan, complex liverwort genus with over 2000 validly published binomials (Yuzawa 1991; von Konrat et al. 2010). Current estimates of the accepted number of species for the genus suggest there are between 300-375 accepted species (e.g., Schuster 1992; Gradstein et al. 2001). However, growing data and evidence suggests that this estimate is overly conservative (von Konrat et al. 2010), and that the full extent of species diversity

\footnotetext{
1 Corresponding author
}

in the genus is possibly much greater (see comments in Heinrichs et al. 2010).

The number of accepted species, including the new species described here, for the New Zealand Botanical Region as defined by Allan (1961), is now 33 (Glenny et al. 2011; von Konrat et al. 2012). Here we present a study of a newly discovered species that is morphologically close to F. rostrata (Hook. f. \& Taylor) Hook. f. \& Taylor. Frullania rostrata was described almost 170 years ago (Hooker 1845). Understandably it was broadly circumscribed, and as such it has usually been 
interpreted as a widepread, polymorphic and common Australasian species (Hattori 1979; von Konrat et al. 2006b). However, recent taxonomic investigations using cryptic morphological characters in conjunction with DNA sequence data has revealed that $F$. rostrata is a species complex, to date with three newly described species segregated from it in New Zealand (von Konrat et al. 2011, 2012). One species, Frullania congesta Gottsche Lindenb. \& Nees was accepted by many authors as a synonym of $F$. rostrata for decades, following Hattori (1978). However, von Konrat et al. (2006a) recognized $F$. congesta as a distinct species, underscoring the important need to examine type material, critically re-examine morphological concepts, and use a broad array of tools at our disposal. This was later reinforced with molecular data (Hentschel et al. 2009) that supported its placement, not only as a distinct species, but in an entirely different subgenus.

Here we continue that process distinguishing from $F$. rostrata a new species which historical herbarium specimens show had been incorrectly placed within that species on the basis of its overall gross morphological similarity. This paper is part of a broader, on-going, collaborative regional study of Frullania species by us that includes the botanical regions of New Zealand, Australia, the Pacific, South East Asia, and South America. The authors on-going investigations also encompasses a systematic revision of several subclades within Frullania, including F. subg. Microfrullania (R. M. Schust.) R. M. Schust., where the new species is placed. The new species as Frullania "sp. indet." in von Konrat et al. (2012) was included in a molecular phylogeny based on the nr ITS2 region and $\mathrm{cp}$ trnL-trn $\mathrm{F}$ intergenic spacer sequences. In that study the new species is nested within other members of $F$. subg. Microfrullania and appears as sister to a clade that included $F$. rostrata accessions and the tropical F. parhamii Pearson. Subsequent to that work, the authors re-examined herbarium specimens, the second author carried our further fieldwork, and together found several morphologically identical specimens that are here ascribed to the new species. Preliminary unpublished molecular assessment of these specimens confirm our morphological observations and its genetic identity, which is very stable and clearly different from $F$. rostrata.

Detailed light microscopic and SEM micrographs as well as a brief comparison with morphologically similar species are provided. The new species, although only known from scant collections has a seemingly broad distribution. Its current range is known from the southernmost main island of New Zealand, Rakiura/Stewart Island, to the northernmost part of the North Island. The plant has obviously been overlooked due to the morphological similarity with the ubiquitous $F$. rostrata described over 170 years ago. For consistency and clarity through this article, the results and discussion that follows refers to the newly recognised species as Frullania toropuku.

\section{METHODS}

HERBARIUM MATERIAL. Dried herbarium material was examined from AK, BM, CANB, CRI, F, G, GOET, MEL, MELU, MPN, NICH, NY, P, S, WELT, and WTU. Herbarium acronyms follow Thiers (2013).

MORPHOLOGICAL STUDY. Where necessary, plant material was cleared to remove pigmentation using the method outlined by von Konrat and Braggins (2001a) and the cell layers of the capsule wall were separated as described by von Konrat et al. (1999). Microscopy techniques, measurements, the use of descriptors to indicate abundance and frequency, terminology of spore ornamentation, preparation of material (including spores for the SEM studies) are outlined in detail by von Konrat and Braggins (2001b) and von Konrat et al. (2006a, b).

SPECIES CONCEPT. Although the determination of species is regarded as one of the most important activities of the taxonomist, the majority of systematists undertaking monographs and revisions of vascular plants do not discuss the concepts or the criteria to delimit species (McDade 1995). A similar statement can undoubtedly be applied to liverwort systematics (von Konrat et al. 2006a, 2010). Here, we adopt a hierarchical model as promoted by Mayden (1997). This model considers the Evolutionary Species Concept as a theoretically robust primary species concept, as well as a bridging, secondary or operational species concept. This is discussed in the context of Frullania by von Konrat et al. (2006a). 


\section{TAXONOMY}

ARTIFICIAL KEY DISTINGUISHING FRULLANIA TORO$P U K U$ FROM MORPHOLOGICALLY ALLIED SPECIES OF F. SUBG. MICROFRULLANIA, INCLUDING THOSE DISTRIBUTED IN NEW ZEALAND.

1. Leaf-lobes with denticulate to coarsely dentate and hyaline margins ................ F. sect. Microfrullania: F. chevalieri (R. M. Schust.) R. M. Schust., F. microscopica Pearson, F. parhamii R. M. Schust. [incl. New Zealand, New Caledonia, and Fiji]

$1^{*}$. Leaf-lobes with entire margins, lacking any form of marginal dentition, and lacking hyaline margin ... 2

2. Stylus with a distinct, subrectangular shape and truncate apex; lobules with a distinctive angular projection immediately above the slit ........ ................ truncatistyla von Konrat, Hentschel, J. Heinrichs \& Braggins [North Island, South Island, Stewart Island]

2* Styli sickle-shaped, subtriangular to triangular; lobules without a distinctive angular projection absent (not to be confused with the \pm discoloured, gibbous, cell above mouth) ......... 3

3. Plants dioicous; perianth 3-keeled, smooth; the first branch leaf (BL1) of a Frullania-type branch often typical of the normal stem leaves, with an explanate dorsal segment and stylus and saccate ventral segment .................. 4

3. Plants monoicous; perianth plicate, 3 major keels +2-3 supplementary keels, the perianth surface conspicuously ornamented, bullate; the first branch leaf (BL1) of a Frullania-type branch often reduced in size and atypical of the normal stem leaves, with all three segments explanate or at most sulcate, and leaves characteristic of the main stem not developing until either BL2, BL3 or BL4 ........... .......F. toropuku [North Island, Stewart Island]

4. Lobules typically at an angle in relation to the stem, leaf-lobe median cells smaller than basal cells and with 3-4 oil-bodies per cell, occupying $<50 \%$ of the area of the cell lumen; perianth typi-

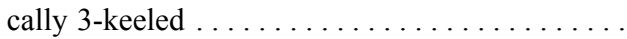
..... F. rostrata s.1. [Australia, New Zealand]

4. Lobules varied, typically subparallel to the stem; leaf lobe median cells forming a band (vitta) of cells as large as basal cells and with 1-2 oil-bodies per cell, occupying almost entire cell lumen; perianth plicate $5-6$ keeled .......... 5
5. Leaf lobes often squarrose; main stem underleaves \pm as wide as stem; leaf lobule clavate, cell walls distinctly flexuose toward the lobule apex ...... ... F. pseudomeyeniana S. Hatt. [New Caledonia] 5. Leaf lobes flat, not squarrose; main stem underleaves wider than stem; leaf lobule cylindrically helmetshaped, cell walls becoming distinctly semi-straight toward lobule apex ................ F. knightbridgei von Konrat \& de Lange [Stewart Island, Auckland Island]

\section{Frullania toropuku von Konrat, de Lange} \& Larraín, sp. nov.

Figs 1-3

Frullaniae rostratae similis, sed statura saepe breviore, statu monoico, elateribus numero minore per capsulam (12-22), lobulo folii ramuli primius saepe paene vel plene explanato differt.

TYPE: NEW ZEALAND, NORTH ISLAND, Te Paki Ecological Region and District, Te Paki, North Cape Scientific Reserve, "Badlands Area", In a small Phyllocladus "forest". Saxi-terricolous - forming a loose crust over serpentine rock and ferrocrete on the margin of a small ephermeral stream draining a large area of heavily eroded ferrocrete and bauxite, c. $180 \mathrm{~m}$., $34^{\circ} 24^{\prime \prime} 2^{\prime} \mathrm{S}, 173^{\circ} 1^{\prime \prime} 16^{\prime} \mathrm{E}, 19$ Oct. 2009 , P. J. de Lange 8038 [HoLOTYPE: AK; ISOTYPE: F].

Plants small (main shoots $300-500 \mu \mathrm{m}$ wide), typically olive-green to occasionally copperbrown, and closely to loosely adhering to substrate. Leading stem to $10 \mathrm{~mm}$ long and to $50 \mu \mathrm{m}$ in diameter (without leaves), 5-6(-7) cells wide, little differentiation between cortical cells (12-16 in no.) and medullary cells (7-10 in no.), former slightly smaller than the latter, both with firm walls, lumen irregularly shaped. Branching often irregularly to occasionally regularly pinnate. Dimorphic branching, with both Frullania-type (FB) and occasionally, Lejeunea-type (LB) branching. Initial appendages of FB: First branch underleaf (BUL1) always with three distinct segments, the ventral lamina divided for $c a 1 / 2$ its length into two subequally sized lobes +1 dorsal lobe which is usually saccate, or occasionally sulcate to explanate. First branch leaf (BL1) varies, either: reduced in size, ventral segment elobulate, and explanate to sulcate, with leaves characteristic of the main stem starting at BL2-BL3(-BL4); or the 
appendages of BL1 \pm characteristic of normal stem leaves (i.e. BL1: 1 explanate dorsal lobe +1 saccate lobule +1 stylus). Initial appendages of LB: BUL1 and BL1-BL3 are always reduced in size and lobule-free, formation of normal lobulate leaves occurring thereafter.

Stem leaves of main branch flat when dry and wet, slightly imbricate to contiguous, suborbicular to broadly oval, to $275 \mu \mathrm{m}$ long $\times 175 \mu \mathrm{m}$ wide with incurved distal margins, and dorsal margins extending beyond the farther edge of the stem, rounded to subacute apices and non-auriculate at the base, margins entire and smooth dorsal surface. Lobules \pm remote from the stem (lobule attached to stem by $3-4$ cells) and at angles of $40-50^{\circ}$ with the stem so that lobules tilted outwards; lobules similar in colour to other organs; cylindrically pitcher-shaped (orbicular in cross-section with up to 24 cells in circumference) and $c a 1.5-2 \times$ long as wide, lobules large (its area obscuring at least $1 / 3 \times$ the exposed area of the dorsal lobe), 110-150 $\mu \mathrm{m}$ long $\times 60-80 \mu \mathrm{m}$ wide; somewhat dorsiventrally compressed near mouth as compared to gibbous upper third, the opening wide, extending along the abaxial lobule margin; $c a 1 / 3$ from lobule mouth there is usually a \pm enlarged and elongated, gibbous, slightly protuberant cell; free margin of lobular mouth crenulate-sinuate, especially near the sinus, usually hyaline near mouth, lobule apex obtuse. Stylus, triangular, \pm large (1/2-2/3 the length of the lobule), 50-75 $\mu \mathrm{m}$ long $\times 30-40 \mu \mathrm{m}$ wide, $5-7$ cells wide $\times 5-9$ cells high (15-25 cells in total), rarely with a slime papilla at apex. Underleaves of leading stems, contiguous or just overlapping with lobules, underleaves contiguous to distant from each other, small ( $c a 0.25$ $\times$ the size of leaf lobes), (1.00-)1.25-1.50(-2.00) $\times$ the stem in width, underleaf usually as long as wide, occasionally slightly wider than long, 80-110 $\mu \mathrm{m}$ long $\times 65-85 \mu \mathrm{m}$ wide, broadest at middle (8-11 cells wide); entire lateral margins; apex of underleaf bilobed to $1 / 2$ its length, lobes separated by a narrowly $\mathrm{U}$ to $\mathrm{V}$-shaped sinus; each lobe with 4-5 cells at the base, lobes with acute to subacute apices. Rhizoid-initial area present near base of underleaf, rhizoids occasionally seen, subhyaline, in short bundles. Microphyllous branching absent, or with pseudo-microphyllous branches where the lobules of secondary stems \pm similar size to main stem, but lobes and underleaves of secondary branches markedly smaller than those of leading stems. Underleaves of secondary branches usually with a V-shaped sinus separating the underleaf lobes, and only 2-3 cells wide at the base of each lobe.

Lobe marginal cells \pm rectangular, hyaline walls subequally thickened, cell cavities brownish red, to 7-9 $\mu \mathrm{m}$ long $\times 7-9 \mu \mathrm{m}$ wide; median cells \pm subquadrate, rectangular, or 5-sided; hyaline walls subequally thickened, intermediate thickening rare to absent, wall thickness to $2 \mu \mathrm{m}$ wide (without intermediate thickenings), cell cavities of median cells brownish red, 8-12 $\mu \mathrm{m}$ long $\times 8-10 \mu \mathrm{m}$ wide; cells becoming gradually larger basally, cavities of the basal median group of cells to $14-18 \mu \mathrm{m}$ long $\times 12-16 \mu \mathrm{m}$ wide; walls of basal cells with subnodulose trigones and occasional intermediate thickenings, walls and cavities brownish red. Median cells of underleaves often with small, hyaline, trigones with no intermediate thickening or with subequally thickened walls so that the trigones become indistinct from the longer walls, cell cavities to $12 \mu \mathrm{m}$ long $\times 12 \mu \mathrm{m}$ wide. Median cells of lobule slightly longer than wide, cell cavities $1.5-2 \times$ long as wide, to $12 \mu \mathrm{m}$ long $\times 7 \mu \mathrm{m}$ wide, walls flexuose with indistinct trigones and small nodulose intermediate thickenings.

Oil-bodies of the leaf lobe median cells 2-3 $(-4)$ per cell, typically small, spherical $(1-) 2-3(-4)$ $\mu \mathrm{m}$ in diam. to ovoid or ellipsoidal $(2-) 2-3(-4)$ $\times(1-) 1-2(-3) \mu \mathrm{m}$, subhyaline, without any significant, visible, internal structure i.e. giving the appearance of being almost homogeneous. The oilbodies are often similar in size or slightly smaller than the chloroplasts; occasionally the oilbodies are larger than the chloroplasts. The oil-bodies of the lobule and underleaf are similar to those encountered in the leaf lobe. Oil-bodies becoming progressively larger towards the basal cells: usually $3-5$ per cell, to $7 \mu \mathrm{m} \times 5 \mu \mathrm{m}$, coarsely granular, ocelli never present. Asexual reproduction not known.

Monoicous (often with the androecium directly posterior to the female bracts or with an- 

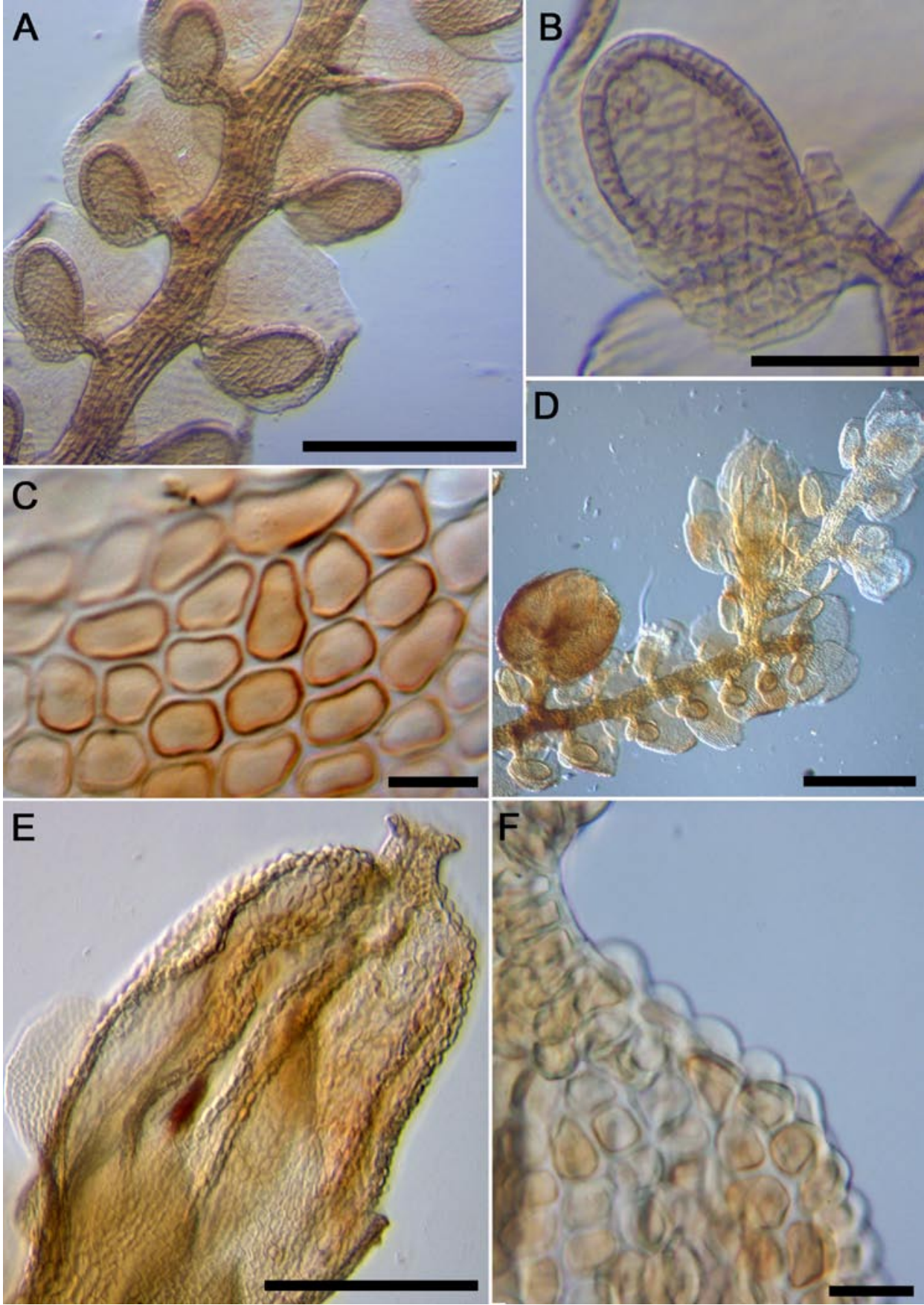

Fig. 1. Frullania toropuku von Konrat, de Lange \& Larraín, sp. nov. A - ventral view of stem, B - leaf-lobule and stylus, $\mathrm{C}$ - median cells of leaf-lobe, D - ventral view of monoicous plant, including an androecium and a short subfloral innovation arising immediately below an unfertilized gynoecium, E - dorsal view of perianth illustrating plicate keels, $\mathrm{F}$ - elevated, conical cells on surface of keel of perianth - Scale bars: A \& $E=250 \mu \mathrm{m} ; \mathrm{B}=50 \mu \mathrm{m} ; \mathrm{C}=15 \mu \mathrm{m} ; \mathrm{D}=500 \mu \mathrm{m} ; \mathrm{F}=20 \mu \mathrm{m}$ (all from holotype, de Lange 8038). 
droecial branches a short distance below the $q$ inflorescence). Androecia subspherical to discoid, $150 \mu \mathrm{m}$ long $\times 150 \mu \mathrm{m}$ wide, usually with 2 pairs of closely imbricate bracts, sessile on leafless stalks or terminal on very short-stalked branches [stalk with 1-2(-4) vegetative leaf lobes]. Gynoecia terminal on main or leading stem. A shoot system often occurring between bracts and perianth (subfloral innovation) or arising 2 complete leaf cycles below the gynoecia or perianth bracts i.e. a subfloral branch. + bracts and bracteoles usually only in 2 pairs. Innermost bract unequally bilobed; bract-lobe lanceolate-elliptical to obovate, to $c a 300 \mu \mathrm{m}$ long $\times 150 \mu \mathrm{m}$ wide, gradually narrowed toward an acute, blunt or obtuse apex, margin entire except 2-3 small teeth at the base; bract-lobule, triangular, to $c a 250 \mu \mathrm{m}$ long $\times 125 \mu \mathrm{m}$ wide, with an acute to subacute apex, on free margins with a single small angulation or tooth near the base; innermost bracteole free from bracts, oblong to obovate, to ca $250 \mu \mathrm{m}$ long $\times$ $175 \mu \mathrm{m}$ wide, about $1 / 3^{1 / 2}$ bilobed, the sinus narrowed, lobes with convex sides, triangular, acute at apex, with entire margins. Marginal cells of bract and bracteole \pm subequally thickened, but towards the median cells, trigones becoming large and bulging. One archegonium per gynoecium. Perianth partially exserted to freely emergent, 400-600 $\mu \mathrm{m}$ long (beak omitted) $\times 225-250 \mu \mathrm{m}$ wide, with 3 rounded keels $+2-3$ supplementary keels, oblong-ovate, tapering towards the apex into a short beak; cells of the perianth surface often each elevated as small, to $c a 4 \mu \mathrm{m}$ high tubercles; perianth beak cylindrical, to $50 \mu \mathrm{m}$ long, rim of the perianth mouth smooth, but the inner beak surface covered with large single-celled protuberances (to $10 \mu \mathrm{m}$ long).
Capsule valves to $275 \mu \mathrm{m}$ long $\times 200 \mu \mathrm{m}$ wide; elaters (12-)14-20(-22) in total (common arrangement on two alternating valves: $1+3 ; 2+3$, elaters rarely arranged in rows of 3 on the valve); unispiral, to $175 \mu \mathrm{m}$ long $\times 15 \mu \mathrm{m}$ wide, elater surface irregularly rugose-granulate. Epidermal cell layer (7-)8-9 cells at the widest region. Epidermal cells with 4-5 sides, the thickenings at the angles of the epidermal cells extend out as lobes; consequently the juxtaposed thickenings of adjoining corners form a (1-) $2(-3)$ unevenly lobed configuration. Inner cell layer: portions of the radial walls are spread irregularly over the free tangential face and are strongly thickened, forming a sinuate partial layer of thickening or jigsaw like pattern. Spores globose, to $43 \mu \mathrm{m}$ at widest axis, interspersed with $8-10$ rosettes; each rosette to $4.5 \mu \mathrm{m}$ in diam., bearing a ring of $6-8$ conspicuous protuberances; these primary projections never papillate or branched, $1-1.51 \times$ as long as wide, $1-1.5 \mu \mathrm{m}$ long $\times 0.75-1.00 \mu \mathrm{m}$ wide at base, gradually tapering to an obtuse or rounded apex; spore wall papillae otherwise densely distributed between regions of the rosettes.

ADDITIONAL MATERIAL SEEN (PARATYPES): NEW ZEALAND, NORTH ISLAND, Coromandel State Forest Park, near summit of Table Mt. On bark of Lepidothamnus intermedius (Kirk) Quinn. Poorly drained, mucky, fine, peat floor in wet mossy forest of Lepidothamnus intermedius, Ixerba brexioides A. Cunn and Dacrydium cupressinum Sol. ex Lamb. with occasional Phyllocladus toatoa Molloy, 790 m., $37^{\circ} 3^{\prime} \mathrm{S}, 175^{\circ} 40^{\prime} \mathrm{E}$, Feb. 1997, M. von Konrat 97/115; LITTLE BARRIER ISLAND, near junction of Track 1 and Thumb Track. Beach/kauri forest, epiphyte on Cyathodes fasciculata (G. Forst.) Allan [sic], 1200 ft., 23 Jan. 1980, J. E. Braggins \& J. E. Beever 80/173; STEWART ISLAND, Rakiura/Stewart Island National Park, in vacinity of

Fig. 2 Frullania toropuku von Konrat, de Lange \& Larraín, sp. nov. A - ventral view of monoicous plant, including 3-keeled perianth, terminal, on a short subfloral innovation arising immediately below an unfertilized gynoecium, B - ventral view, an unfertilized gynoecium with an androecium (m) immediately posterior to the female bracts, $\mathrm{C}$ - a subfloral innovation (lateral branch) replacing the outermost bract-lobule of the female bract of a gynoecium, D - ventral view of perianth and subfloral innovation, E - dorsal view of perianth with cells slightly elevated, F - leaf-lobule, cylindrically pitcher-shaped, somewhat dorsiventrally compressed near mouth as compared to gibbous upper third, the opening wide, extending along the abaxial lobule margin; $c a 1 / 3$ from lobule mouth there is a \pm enlarged and elongated, gibbous, slightly protuberant cell, $\mathrm{G}-$ surface of perianth, cells elevated as small tubercles, $\mathrm{H}$ - ventral view of main stem, I - perianth beak, cylindrical, rim of the perianth mouth smooth, but the inner beak surface covered with large single-celled protuberances. Scale bars: A, C, D = 200 $\mu \mathrm{m} ; \mathrm{B}, \mathrm{E}, \mathrm{H}=100 \mu \mathrm{m}$; $\mathrm{F}=50 \mu \mathrm{m} ; \mathrm{G}, \mathrm{I}=20 \mu \mathrm{m}$ (all from paratype von Konrat 97/115). 

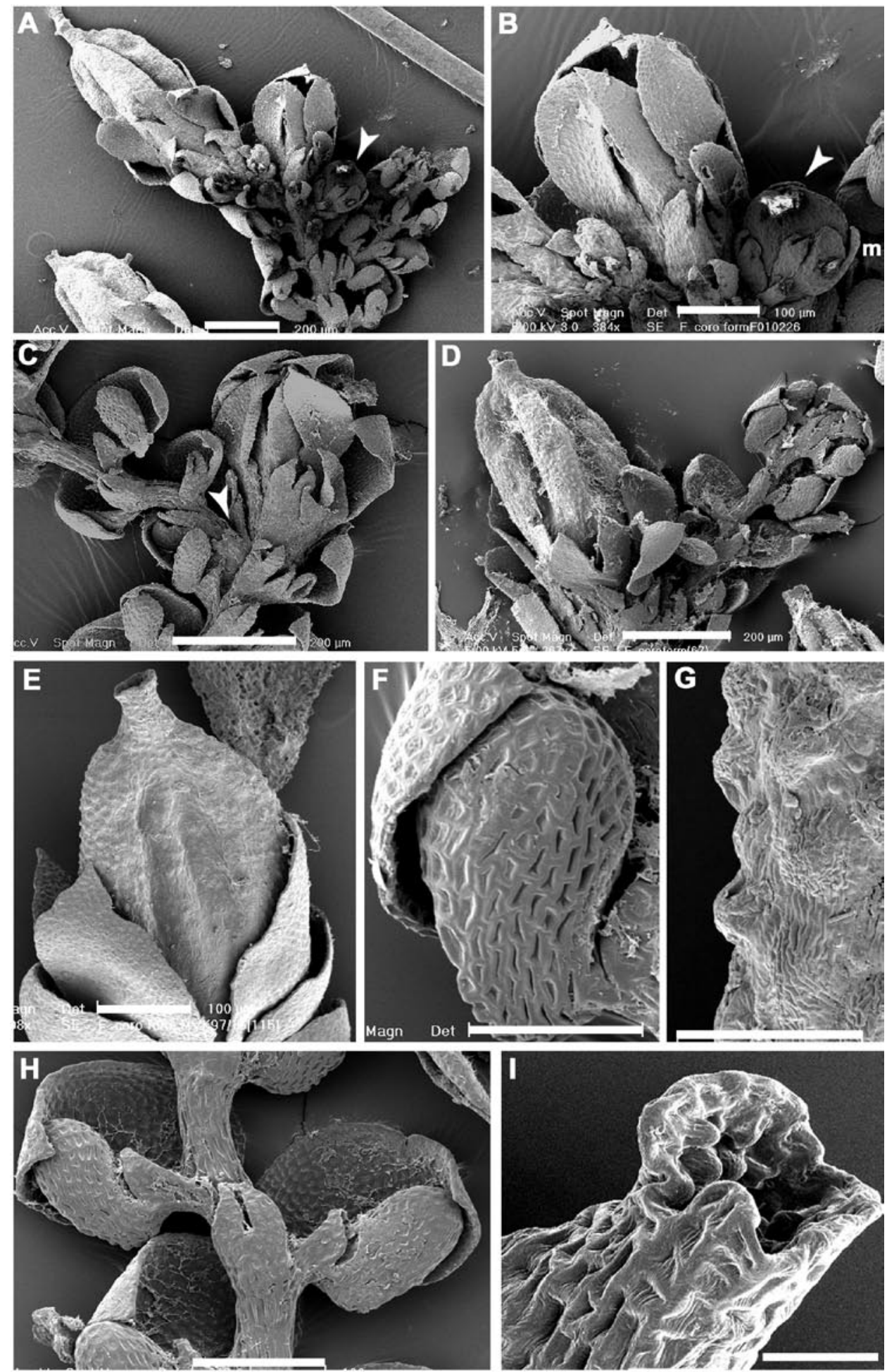

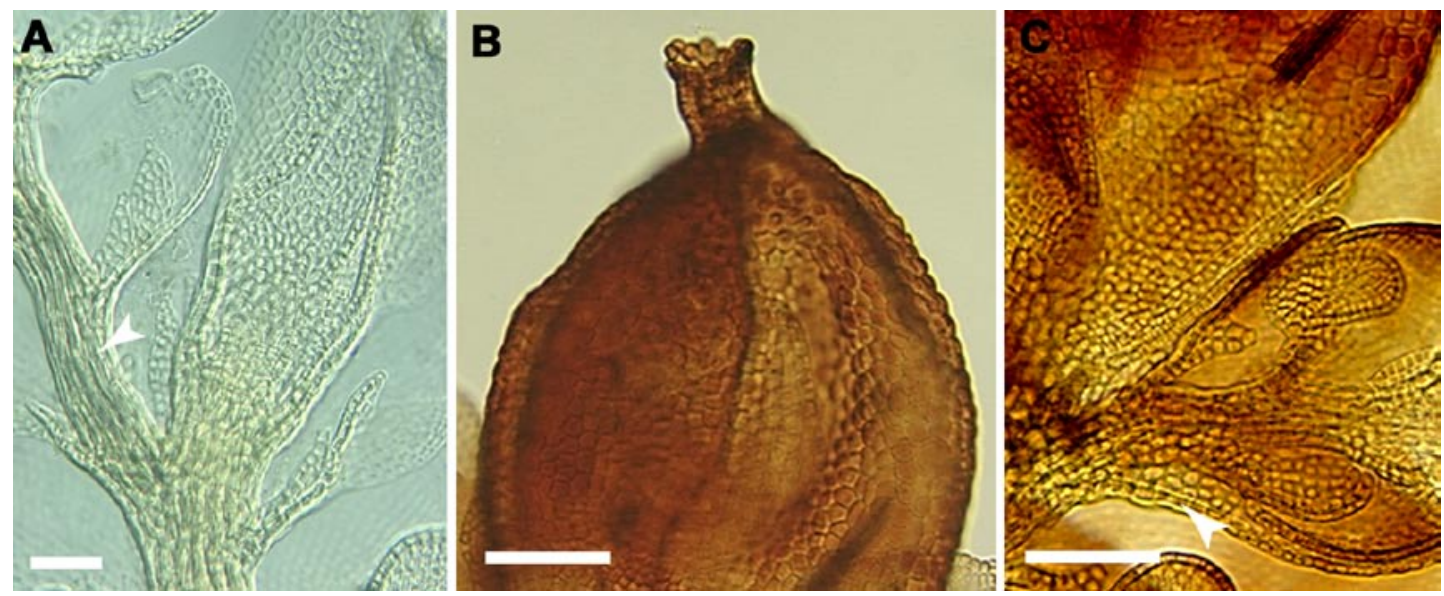

Fig. 3. Frullania toropuku von Konrat, de Lange \& Larraín, sp. nov. A - a subfloral innovation replacing the outermost bractlobule of the female bract of a gynoecium, B - upper portion of perianth, illustrating the raised or elevated cells, C - subfloral innovation, immediately posterior to the gynoecium Scale bars: $\mathrm{A}=50 \mu \mathrm{m}$; B \& $\mathrm{C}=100 \mu \mathrm{m}$ (all from paratype von Konrat 97/115).

North Arm Hut near Paterson Inlet, on bark of stunted Dacrydium cupressinum, admixed with Frullania falciloba Taylor ex Lehm., F. fugax (Hook. f. \& Taylor) Taylor ex Gottsche, Lindenb. \& Nees and Frullania congesta Hook. f. \& Taylor ex Gottsche, Lindenb. \& Nees, 12 Dec. 1999, M. von Konrat 99/12-15.

DisTRIBUTION. Endemic to New Zealand where it is so far known from several, seemingly disjunct localities from North Cape, Hauturu - Little Barrier Island, the southern Coromandel Peninsula and then Stewart Island. This pattern is undoubtedly artificial, and we believe that further careful collecting is likely to find further populations between these three locations.

ETYMOLOGY. The epithet 'toropuku' is derived from Te Reo, the language of the Maori people of Aotearoa - New Zealand, and which means 'secretive' and 'mysterious' (Moorefield 2005). This aptly describes the cryptic nature of this species which has undoubtedly contributed to its failure to be noticed by New Zealand hepaticologists.

\section{ECOLOGY}

Considering its recent date of recognition and its cryptic nature very little is known about the ecology of Frullania toropuku. The only detailed study of its habitats and associated species come from observations made at North Cape of the North Island. There it was locally common at $180 \mathrm{~m}$ a.s.l., in a very small area of Phyllocladus aff. trichomanoides D. Don and Metrosideros excelsa Sol. ex Gaertn. forest overlying weathered serpentinite and ferrocrete soils. Within the understorey associated vascular plants included Cassinia amoena Cheeseman, Geniostoma ligustrifolium var. crassum Cheeseman, Coprosma spathulata subsp. hikuruana de Lange \& Heenan, Pittosporum pimeleoides subsp. majus R. C. Cooper, Pseudopanax aff. lessonii (DC.) K. Koch, Astelia banksii A. Cunn., Leptecophylla juniperina (J. R. Forst. \& G. Forst.) C. M. Weiller, Leucopogon xerampelinus de Lange, Heenan \& M. I. Dawson, Pteridium esculentum (G. Forst.) Cockayne and masses of the parasitic vine Cassytha paniculata R. Br. In this dense vegetation the Frullania grew in heavy shade, in one site, on serpentinite saprolite and an associated 'mix' of ferrocrete colluvium and, to some extent, alluvium that had been washed down stream from an adjacent erosion gully. In this habitat the Frullania was dominant though it grew in loose association with Heteroscyphus cuneistipulus (Steph.) Schiffn. and H. triacanthus (Hook. f. \& Taylor) Schiffn. The habitat occupied here is as much drought prone as it is subjected to frequent flash floods. Whilst the climate of North 
Cape is generally very dry, the area is often subjected to lengthy periods of immersion in dense sea fogs which also provide much moisture. Nevertheless the liverwort flora of the serpentinised zone of that area (in which F. toropuku has only been found) is rather depauperate with less than 80 taxa known from the 120 ha serpentinite exposure (P. J. de Lange unpubl. data).

Nothing could be more contrasting than the population found on Table Mountain of the Coromandel Peninsula, North Island, an $800 \mathrm{~m}$ high, dish shaped, eroded remnant of a solidified crater lake. Here the high rainfall and altitude have contributed to produce a montane 'cloud forest' overlying a very poorly draining forest peat. The dominant trees in this habitat comprise tortured and twisted Lepidothamnus intermedius and Manoao colensoi (Hook.) Molloy, through which Metrosideros umbellata Cav., Weinmannia sylvicola Sol. ex A. Cunn., Ixerba brexioides, Dracophyllum traversii Hook. f., D. latifolium A. Cunn. and the uncommon shrubby Epacris sinclairii Hook. f. and Dracophyllum patens W. R. B. Oliv. are characteristic vascular species. The high rainfall, closed 'cloud forest' canopy and poor drainage provide an excellent habitat for bryophytes, the full diversity of which has yet to be properly examined.

Similarly, Stewart Island, the southernmost of the three major islands of New Zealand, where F. toropuku was also collected, has a highly oceanic climate, humid, with rainfall evenly spread throughout the year (McGlone \& Wilson 1996). Frullania toropuku was collected in a stunted Dacrydium cupressinum and Metrosideros umbellata forest near Patternson Inlet where it was growing admixed with $F$. falciloba, $F$. fugax and F. congesta.

These observations suggest that $F$. toropuku has no immediately obvious ecological preferences. Clearly further field study of its habitats is necessary.

\section{CONSERVATION STATUS}

Frullania toropuku, being known only from four widely disparate localities, and with minimal data on its abundance, ecology and threats readily quali- fies as 'Data Deficient' using the New Zealand Threat Classification System (Townsend et al. 2008).

\section{DISCUSSION}

In many respects this species is not markedly different from smaller forms of $F$. rostrata, with which it is closely allied too, and with which it grows in close proximity at least at North Cape. However, the two species are distinguishable as indicated in the key. Four salient features that together characterise $F$. toropuku include: 1 ) the monoicous habit; 2) the perianth with an ornamented surface; 3 ) the small number of elaters per capsule (only 12-22); 4) features associated with the first branch leaf (BL1) of a Frullania-type branch; often reduced in size and atypical of the normal stem leaves, with all three segments explanate or at most sulcate, and leaves characteristic of the main stem not developing until either BL2, BL3 or BL4; and 5) occasionally having Lejeunea-type branching. Dark-brown pigmented forms of $F$. toropuku may possibly be mistaken for another, very small, New Zealand species, F. truncatistyla, but the large, rectangular, stylus, which has a truncate apex, easily differentiates the latter. The lobule of $F$. toropuku also lacks the specialised, protruding cell, which is a critical feature of $F$. truncatistyla.

Previously, Schuster (1970, 1992) noted that a southern South American species, F. microcaulis [as Amphijubula microcaulis (Gola) R. M. Schust.] had the least number of elaters per capsule for Frullania species, ranging from a total of 10-20 elaters, and partly on that basis, stated that $F$. $m i$ crocaulis, had a unique position - either as it's own subgenus within Frullania or that it should be maintained at the generic level. However, some specimens of $F$. toropuku may also have, as few as 12 , or as many as 22 elaters per capsule; this is the only other species of Frullania with such a low number of elaters. Interestingly, by inference, one can most likely discount the possibility that the small number of elaters per capsule valve is a function, or a product, of the small size of the capsule valve per se; the smallest forms of $F$. rostrata s. str. and F. hodgsoniae von Konrat, 
Braggins, Hentschel \& J. Heinrichs (which have capsules valves similar in size to those of $F$. toro$p u k u$ ) consistently have a greater number of elaters per capsule valve than $F$. toropuku.

\section{CONCLUSION}

The challenge of recognizing synonyms and sibling species is clearly enormous, yet the growing number of molecular studies at the species level will aid efforts in quantifying the contribution of cryptic or near-cryptic species to the global biodiversity of liverworts. The majority of these studies have been confined to sequence data. However, Vanderpoorten and Shaw (2010) encourage bryophyte systematists working at the species level to supplement sequence data with information from other kinds of markers that are better suited to recently diverged taxa, suggesting that DNA fingerprinting methods including RFLPs, ISSRs, and microsatellites, are especially useful for many species-level systematic problems. It is clear, we urgently need more species-level molecular investigations with extensive population sampling to approximate the actual diversity of Frullania, and to elucidate speciation processes and distribution range formation (Heinrichs et al. 2010; Ramaiya et al. 2010). Nonetheless, monographic and revisional work based on detailed morphological investigation will remain fundamental. Frullania rostrata is a very good example that was previously considered a polymorphic species, yet detailed morphological studies combined with supporting molecular evidences is revealing a growing number of well defined aggregate species with well supported morphological boundaries. Examination of live material coupled with critical study of fertile reproductive structures is critical in Frullania and some of the apparent cryptic species may not be so cryptic afterall in some species complexes.

ACKNOWLEDGEMENTS. The senior is deeply grateful to the Department of Conservation, New Zealand, for collecting permits throughout the various Conservancies of New Zealand, particularly Paul Cashmore for facilitating permits and Department of Conservation staff based at Stewart Island/Rakiura as well as the Southland Conservancy for logistical support. The finan- cial assistance of Caterpillar Inc., National Geographic Committee for Research (Award No. 7379-02), GBIF Seed Money (Award No. 2007/41), and the National Science Foundation (Award Nos. 1115116, DEB1145898, DEB1146168) is gratefully acknowledged. We thank Anders Hagborg and Lars Söderström the Early Land Plants Today (ELPT) for access to nomenclatural data and to the Pritzker Lab, The Field Museum. Both Peter de Lange and Matt von Konrat would like to thank Ngati Kuri the iwi who exercise mana whenua over Te Paki for access to and permission to collect liverworts from North Cape. Peter de Lange also acknowledges the considerable field assistance received from the staff of the former Kaitaia Area, Department of Conservation who provided vehicles and accommodation during field surveys at North Cape. Also we thank Jeremy Rolfe, Andrew Townsend, John Braggins, John Engel and Janeen Collings for company in the field. Finally we thank Patricia Eckel for providing the Latin diagnosis, and the curators of the herbaria cited in the text for providing specimens.

\section{REFERENCES}

Allan H. H. 1961. Flora of New Zealand. 1. Wellington, Government Printer.

Glenny D., Fife A. J., Brownsey P. J., Renner M. A. M., Braggins J. E., Beever J. E. \& Hitchmough R. 2011. Threatened and uncommon bryophytes of New Zealand (2010 revision). New Zealand J. Bot. 49: 305-327.

Gradstein S. R., Churchill S. P. \& SAlazar-Allen N. 2001. Guide to the Bryophytes of Tropical America. The New York Botanical Garden Press, New York.

HATTORI S. 1978. A small collection of Frullania species made on Auckland Island group. Miscell. Bryol. Lichenol. 8: 45-46.

HATTORI S. 1979. A revision of the Australasian species of the Frullania, Hepaticae, I. J. Hattori Bot. Lab. 45: 323-363.

Heinrichs J., Hentschel J., Bombosch A., Fiebig A., Reise J., EdelmanN M., KREIER H.-P., SCHÄFER-VERWIMP A., CASPARI S., SCHMIDT A. R., ZHU R.-L., VON KonRAT M., SHAW B. \& SHAW A. J. 2010. One species or at least eight? Delimitation and distribution of Frullania tamarisci (L.) Dumort. s. 1. (Jungermanniopsida, Porellales) inferred from nuclear and chloroplast DNA markers. Molec. Phylogenet. Evol. 56: 1105-1114.

Hentschel J., VON KONRAT M. J., PÓCS T., SCHÄFER-VERWIMP A., SHAW A. J., SCHNEIDER H. \& HEINRICHS J. 2009. Molecular insights into the phylogeny and subgeneric classification of Frullania Raddi (Frullaniaceae, Porellales). Molec. Phylogenet. Evol. 52: 142-156. 
HoOKer J. D. 1845. The Botany of the Antarctic Voyage of H. M. discovery ships Erebus and Terror in the years 1839-1843. 1. Reeve Brothers, London.

MAYDEN R. L. 1997. A hierarchy of species concepts: the denouement in the saga of the species problem. In M. F. Claridge, H. A. Dawah \& M. R. Wilson (eds.), Species. The Units of Biodiversity, pp. 381-424. Chapman \& Hall, London.

MCDADE L. A. 1995. Species concepts and problems in practice: insight from botanical monographs. Syst. Bot. 20: 606-622.

MCGLONE M. S. \& WiLSON H. D. 1996. Holocene vegetation and climate of Stewart Island, New Zealand. New Zealand J. Bot. 34: 369-388.

MoOREFIELD J. C. 2005. Te Aka: Māori-English, English-Māori Dictionary. Longman/Pearson, Auckland.

Ramaiya M., Johnston M. G., Shaw B., Heinrichs J., Hentschel J., von KonRat M., Davison P. G. \& ShaW A. J. 2010. Morphologically cryptic biological species within the liverwort, Frullania asagrayana. Amer. J. Bot. 97: 1707-1718.

SCHUSTER R. M. 1970. Studies on antipodal hepaticae, III. Jubulopsis Schuster, Neohattoria Kamimura, and Amphijubula Schuster. J. Hattori Bot. Lab. 33: 266-304.

SCHUSTER R. M. 1992. The Hepaticae and Anthocerotae of North America east of the hundredth meridian. 5. Field Museum of Natural History, Chicago.

THIERS B. 2013. Index herbariorum: A global directory of public herbaria and associated staff. New York Botanical Garden's Virtual Herbarium. http://sweetgum.nybg.org/ih/ (accessed 25 September 2013).

Townsend A. J., DE LANGe P. J., Norton D. A., Molloy J., Miskelly C. \& Duffy C. 2008. The New Zealand Threat Classification System manual. Department of Conservation, Wellington.

VANDERPOORTEN A. \& SHAW A. J. 2010. The application of molecular data to the phylogenetic delimitation of species in bryophytes: a note of caution. Phytotaxa 9: 229-237.
VON KONRAT M. \& BRAGGINS J. E. 2001a. A taxonomic assessment of the initial branching appendages in the liverwort genus Frullania Raddi. Nova Hedwigia 72: 283-310.

von Konrat M. \& Braggins J. E. 2001b. Notes on five Frullania species from Australia, including typification, synonyms, and new localities. J. Hattori Bot. Lab. 91: 229-263.

VON KonRat M., Harris P. J. \& Braggins J. E. 1999. A new technique to investigate cell layers of the capsule wall using Frullania (Hepaticae) as a case study. Bryologist 102: $240-248$.

VOn Konrat M., Braggins J. E., Asakawa Y. \& Toyota M. 2006a. Recognition of Frullania congesta: a case study to present a species concept and a synthesis of significant taxonomic characters for the large liverwort genus Frullania (Frullaniaceae). J. Hattori Bot. Lab. 100: 553-576.

von Konrat M., Braggins J. E., AsAKaWA Y. \& TOYOTA M. 2006b. Frullania chevalieri (Jubulaceae) in New Zealand, with a reassessment of Schusterella. Bryologist 109: $141-156$.

von Konrat M., Hentschel J., HeinRIChS J. \& Braggins J. E. 2011. Deep Southern Hemisphere Connections: A Revision of Frullania sect. Amphijubula. Bryologist 114: 52-66.

VON KonRat M., HentSChEl J., HeInRICHS J., BRAGGINS J. E. \& Pócs T. 2010. Forty-one degrees below and sixty years in the dark: Frullania sect. Inconditum, a new section of Australasian Frullania species including F. colliculosa, sp. nov. and F. hodgsoniae, nom. and stat. nov. Nova Hedwigia 91: 471-500.

VOn Konrat M., DE LANGE P., Greif M., Strozier L., HentSCHEL J. \& HEINRICHS J. 2012. Frullania knightbridgei, a new liverwort (Frullaniaceae, Marchantiophyta) species from the deep south of Aotearoa-New Zealand based on an integrated evidence-based approach. PhytoKeys $\mathbf{8}$ : 13-36.

YuZAWA Y. 1991. A monograph of subgen. Chonanthelia of gen. Frullania (Hepaticae) of the world. J. Hattori Bot. Lab. 70: 181-291. 